\title{
The Correlation Between the Creative Thinking Tendency of Mathematics Teacher Candidates and Their Attitudes Towards Instructional Technologies and Material Design Lesson
}

\author{
Selin (İnağ) Çenberci ${ }^{1, *} \&$ Ayşe Yavuz ${ }^{1}$ \\ ${ }^{1}$ Necmettin Erbakan University Ahmet Keleşoğlu Education Faculty, Konya, Turkey \\ *Correspondence: Ahmet Keleşoğlu Education Faculty, Necmettin Erbakan University, Konya, Turkey. E-mail: \\ scenberci@konya.edu.tr
}

Received: April 30, 2018

Accepted: May 24, 2018 Online Published: June 24, 2018

doi:10.5430/wje.v8n3p95

URL: https://doi.org/10.5430/wje.v8n3p95

\begin{abstract}
Instructional Technologies and Material Design (ITMD) lesson is a tool that enables Mathematics teacher candidates to design materials for contributing to lasting learning of their students, and use them most effectively. This lesson helps students to activate their creative thinking skills, increase their courage and self-confidence, find different solutions in the face of problems, and therefore introduce creative products. In this context, firstly, it is aimed to examine the level of Mathematics teacher candidates' attitudes towards the Instructional Technologies and Material Design lesson and their effects in terms of different variables in this study and then determine whether there is a relationship between creative thinking tendencies of Mathematics teacher candidates and their attitudes towards Instructional Technologies and Material Design lesson in this study. The sample of the research constitutes of 315 Mathematics teacher candidates who are studying in Mathematics Education Department spring semester of the 2016-2017 academic year of at Necmettin Erbakan University. The data were obtained by applying Marmara Creative Thinking Tendency Scale (MCTTS) developed by Özgenel and Çetin (2017) and whose validity and reliability studies were conducted to teacher candidates, and by applying the Attitude Scale towards Instructional Technologies and Material Design Lesson (ASITMD) developed by Çetin, Bağçeci, Kınay, Şimşek (2013) and whose validity and reliability studies were conducted. There was no significant difference between the Attitudes towards Instructional Technologies and Material Design Lesson and the Creative Thinking tendencies, in terms of gender variable, but it was found significant difference in terms of the high school graduation variable. However, it was obtained that there is a positive and non significant relationship between creative thinking tendencies of Mathematics teacher candidates and their attitudes towards Instructional Technologies and Material Design lesson.
\end{abstract}

Keywords: creative thinking, ITMD, mathematics teacher candidate

\section{Introduction}

\subsection{Introduce the Problem}

In today's educational understanding, instead of individuals accepting ready information without questioning, educating individuals who know what, why and how they should learn, analyze, think creatively and critically, use the learned information in daily life and produce new information, comes to the fore. Teachers are the most important element in providing quality, eligible training to students in line with these goals. The fact that the teachers to whom we entrust our children are going to do such important tasks increases value of both the training and the education given to teacher candidates further. The mathematics course is a profession that students generally approach with prejudice. In this respect, the lessons that Mathematics teacher candidates take are remarkable. When considering the aims of today's Mathematics education understanding, "Instructional Technologies and Material Design" lesson which gives different view points and different thinking opportunities to students is one of the most important lesson. According to the definition of by the Council of Higher Education the aim of "Instructional Technologies and Material Design" lesson is to design, implement and evaluate the materials used to make teaching-learning processes be effective and efficient (Kaya, 2006). Saka and Saka (2005) stated in their study that ITMD lesson is beneficial for students to 
develop their ability in use of teaching materials.

At the same time, the ITMD lesson aims to provide Mathematics teacher candidates to gain important qualities and skills including cognitive, physical and affective attitudes and behaviors in the teaching-learning process when they practice teaching proffession. This lesson makes learning for mathematics teacher candidates more enjoyable, and aims to guide them to make learning process be more enjoyable by embodying the subjects which are abstract and difficult to be learned. Not only do the use of appropriate learning materials not only catch students attention as visual but also allow them to do necessary applications on material. This is one of the most important issues that take into account the existence of students with all kinds of learning styles and make the ITMD lesson be effective vocational lessons.

It is expected that the teacher candidates especially mathematics teacher candidates who have taken this lesson are able to identify the materials that they can use in the lessons and use them effectively and that they are able to produce these materials. Gündüz \& Odabaşı (2004) stated that teacher candidates should acquire the ability of knowing and using various teaching materials after they have taken this lesson; and in addition they should acquire the ability to develop new teaching materials and update existing materials. The most important factor in achieving this level of efficiency from the ITMD lesson is the attitude of teacher candidates towards this lesson. Erden (1995) stated in his study that attitude of the students is the most important affective characteristic of a lesson. İnceoğlu (2010) defined the attitude as "mental, emotional, and behavioral response predisposition that the individual organizes based on experience, knowledge, emotion and motivation against any object, social subject, or event in his or her surrounding environment". The positive attitude of the Mathematics teacher candidates about the lesson is one of the most important indicators whether they can reach the goals of the lesson. Since efforts should be made to change their negative attitude as students think that mathematics is a difficult lesson. Tutkun \& Koç (2001) pointed out that the knowledge, attitudes and skills gained in ITMD lessons is guide for teachers in using the teaching-learning process more effectively. Kolburan Geçer (2010) stated in the study that ITMD lesson influences creativity skills positively, and that provides opportunity for having the ability to look at events from different viewpoint and to design effective materials.

Creativity is defined as "the ability to design, find, and implement something new and unique that is considered to be possessed by everybody" in the Turkish Language Association dictionary (TDK, 1995). Creativity is mentioned together with the skill, attitude and tendency in the literature. In addition to, the attitude is defined by Demirel (2010) as the learned tendency which causes 'the individual to behave in certain ways against certain people, objects and situations'. Skill is defined as qualification that enables an individual to do a job (Turan, 2015) whereas the tendency is 'the approach or tendency from heart in order to like, want or do something (TDK, 2015). We can say that researches on creativity, skill, tendency, attitude and other related features help to understand and develop creativity. In order that the creativity can be developed and acquired, and something new can be designed by students, an appropriate education and training environment is needed. Edwards (2006) emphasized in the study that it is needed to develop problem-solving skills of students for designing creative teaching programs and also support group working, and provide a safe environment for experiencing new learning styles by them. This requires a lesson environment in which individuals can freely talk, say and discuss their thoughts. At this point, the importance of the ITMD lesson can not be ignored. Yıldırım (2007) emphasized the necessity of providing suitable environments for creative ideas to be produced, in the study named 'The importance of the creativity and its management in the age of information'. Yanpar (2009) found that making creativity-based material designs with groups in the ITMD lesson had a positive effect on the student's portfolio scores. Erleddson (1999) suggests that creative thinking skills exist a little in all individuals. It can be emphasized that creativity tended to use the creative thinking ability of the individual. In addition, it was reached to conclusion that working collaboratively in the process of designing computer aided materials improves the creative thinking skills of teacher candidates (Birişçi \& Karal, 2011). Creative thinking tendencies are defined as "the desire to use or tendency to use the creative thinking capacity that an individual possesses", and it was determined what these trends are. These are sorted as search for innovation, the courage, self-discipline, curiosity, doubt, and flexibility (Özgenel \& Çetin, 2017). It is clear that using the creative teaching environment will contribute to creative thinking tendencies of students. When considering in this context, ITMD lesson is one of the most efficient lessons at which the creative thinking environment can be created by Mathematics teacher candidates. It is thought that mathematics teacher candidates have high creative thinking tendency at the ITMD lesson and to produce creative things cause a positive effect on their attitudes towards this lesson.

\subsection{Literature Review}

Güneş and İskenderoğlu (2014) conducted a study in which 186 mathematics teacher candidates participated by combining qualitative and quantitative methods in order to determine the attitudes of the teacher candidates studying at 
elementary mathematics teaching department towards Instructional Technology and Material Design (ITMD) lesson. As a result of the research, elementary school mathematics teacher candidates stated that the biggest contribution of the ITMD lesson is to give them the teaching experience and achive the teaching feeling. At the same time, they reached to the conclusion that mathematics teacher candidates certainly agree that ITMD lesson is useful.

Kinay, Şimşek, Bağçeci and Çetin (2015) compared the attitudes of the teacher candidates towards the ITMD lesson in terms of student achievement, computer use levels, gender and class levels. "Attitude Scale towards Instructional Technology and Material Design" lesson developed by researchers themselves was used as a data collection tool. As a result, it was determined that the attitudes of teacher candidates towards ITMD lesson were in high level. In addition to this, there was a significant difference between the attitudes of the teacher candidates towards ITMD lesson according to their course achievements and the computer use level. However, there was no significant difference between their attitudes towards ITMD lesson when they were examined according to their gender and the classes at which they studied.

The study of Alım which was done in 2015 forms the last part of his previously published studies named Instructional Technology and Material Development (ITMD) lesson and suggestions on the Importance of the Teaching Process (Alım, 2007) and Material Design for Geography Lessons (Alım, 2012). Alım, in the study which was done in 2007, presented various teaching materials by giving information about including of the lesson in the curriculum, the importance and aim of the lesson. While in the research which was done in 2012, Alım aimed to reveal the extent to which geography teacher candidates had reached to learning outcomes with the Instructional Technology and Material Design lesson. According to the results of the research in 2015, while the level of reaching to learning outcomes is not differentiated according to sex, it was found out that it differs according to the interest on teaching technology.

İnan (2006), in his study, presented the materials designed for teaching mathematics by explaining the importance of developing and using materials in mathematics teaching. As a result of the study, it was found that the importance of using materials in the disappearing of rote-learning, and it was determined that the positive attitudes of the teacher candidates towards the ITMD lesson increase as their achievements increase.

Gür and Kandemir (2006), emphasized the importance of using class activities to examine the social skills of the students and to ensure their individual development in the study named 'Creativity and Mathematics Education'.

Özer and Tunca (2014), in their study, examined views of teacher candidates on designing and using materials, and it was revealed that teacher candidates give importance to use materials in teaching in order to make them learn more permanently. That teacher candidates are willing to use materials in their professional lives is also the other result of the research.

İşleyen and Küçük (2013) examined the creative thinking levels of classroom and science teacher candidates in terms of different variables in their study. They used Torrance creative thinking test in the study, and also emphasized on the importance of creative thinking. In addition to this, it was found that there was no significant difference in the subject of creative thinking between teacher candidates in terms of their gender and expertise field in the study. However, it was determined that there is a difference in grades of fluency and content richness subscale in favor of classroom teacher candidates.

Aslan and Cansever, in the study which was done in 2009, examined the attitudes of elementary school teachers on the importance of the creativity and using the creavity in the education system. As a result, it was determined that teachers made efforts to use creativity.

Uzunöz, Aktepe and Gündüz (2017) examined the views of teacher candidates about Instructional Technologies and Material Design (ITMD) lesson in different dimensions. It was determined that ITMD lesson contributed to their individual and social development of teacher candidates, brought positive perspectives to educational environments and developed critical and creative thinking skills.

Özgenel and Çetin (2017) developed a scale to determine the tendencies of creative thinking in their study. They conducted validity and reliability studies of the Marmara Creative Thinking Tendency Scale (MCTTS), which was developed by taking into account the factors called search for innovation, the courage, self-discipline, curiosity, doubt and flexibility. In general, this scale measures creative thinking tendencies.

Bakaç and Özen investigated whether there was a relationship between creativity perceptions of teacher candidates, their material design self-efficacy beliefs, and their attitudes towards Instructional Technologies and Material Design lesson in their study which was done in 2016. As a result of the research, it was determined that there was not any significant difference in creativity perceptions of teacher candidates who took ITMD lesson according to their department. With this, it revealed that the self-efficacy belief levels of teacher candidates for designing the material 
were positively influenced as their self-efficacy beliefs for material preparation increased.

Bakaç and Özen (2017), in another study, examined material design self-efficacy beliefs of teacher candidates in terms of technological pedagogical field knowledge proficiency levels by using the descriptive survey model. The data related to the research were collected by Material Design Self-Efficacy Belief Scale and Technopedagogical Education Proficiency Scale. As a result of the research, it was determined that there was a moderate, positive and significant relationship between the material design self-efficacy beliefs of the teacher candidates and their technological pedagogical field knowledge proficiency levels.

\subsection{Explore Importance of the Problem}

Mathematics teachers are the most important element in providing qualified, eligible education to students. The fact that Mathematics teachers to whom we entrust our children are so important increases the value of education given to teachers and teacher candidates so much more. It is known how much the creative thinking is important in the training of teacher candidates. mathematics teacher candidates who have creative thinking awareness will be able to design creative materials during the lessons in their professional teaching life, and will be able to actively use these creative materials at the same time. The importance of ITMD lesson is clear in the dimension of designing and using lesson materials by mathematics teacher candidates, and it is thought that effect of the lesson on creativity of mathematics teacher candidates is important. In order to be able to have a creative idea and to design these materials, the field knowledge of them on the subjects should be sufficient. In this context, ITMD lesson is of great importance both in terms of being able to get a grasp of the subjects, and conveying them in a more permanent way.

It is seen that there are deficiencies in the literature about the examination of the creative thinking tendency of Mathematics teacher candidates and their attitudes towards Instructional Technologies and Materials Design lesson. Therefore, it was aimed to determine whether there is a correlation between their attitudes towards ITMD lesson and the creative thinking tendencies.

\subsection{Research Questions}

When considering the importance of the creative thinking tendency of Mathematics teacher candidates and their attitude variables towards ITMD lesson in mathematics teacher training, it is clear that the results of these researches will contribute significantly to the literature. For this reason, in this study, it was aimed to investigate the effects of the attitudes of mathematics teacher candidates on the Instructional Technologies and Material Design lesson in terms of different variables and investigate the relationship between their creative thinking tendencies and the attitudes towards Instructional Technologies and Material Design lesson.

For this purpose, the sentence of "Is there any relationship between the creative thinking tendencies of the Mathematics teacher candidates studying at the Mathematics education department and their attitudes towards Instructional Technologies and Material Design lesson?" was determined as problem question. In this context, answer was sought for the following sub-problems.

1. What is the attitude level of Mathematics teacher candidates towards Instructional Technologies and Material Design lesson?

2. Do the attitudes of Mathematics teacher candidates towards Instructional Technologies and Material Design lesson differ significantly in accordance with gender?

3. Do the attitudes of Mathematics teacher candidates towards Instructional Technologies and Material Design lesson differ significantly in accordance with high school from which they graduated?

4. What is the creative thinking tendency level of Mathematics teacher candidates?

5. Is there any correlation between the creative thinking tendency scores of the Mathematics teacher candidates and their scores of attitudes towards Instructional Technologies and Material Design lesson?

\section{Method}

The correlative investigation model was used in the research (McMillan \& Schumacher, 2006). This model is one of the most commonly applied models in the related literature (Cohen et al., 2003). The correlative investigation model is used to determine the correlation between different variables in educational and social research (Fraenkel \& Wallen, 2000; Beyhan, 2013) and aims to identify the existence or level of coordinated change between two or more variables (McMillan \& Schumacher, 2006). 


\subsection{Universe and Sample}

The universe of the study constitutes of the teaching candidates who are studying in the spring semester of the 2016-2017 academic year in mathematics Education Department at Necmettin Erbakan University. Since reaching to the whole of the universe was not possible under the present conditions, the way of selecting sample was preffered and sample was selected from Mathematics teacher candidates with disproportionate sampling method. Since the 10 of the 325 Mathematics teacher candidates did not fill the questionnaire as requested, they were not evaluated,-and 315 mathematics teacher candidates formed the sample of the research.

\subsection{Data Collection Tool}

When collecting the data, the Marmara Creative Thinking Tendency Scale (MCTTS), which was developed by Özgenel and Çetin in 2017, and whose validity and reliability studies were made, was used to measure general creative thinking tendencies of the participants (Özgenel and Çetin, 2017). In order to determine the attitudes towards Instructional Technologies and Material Design lesson, the Attitude Scale towards Instructional Technologies and Material Design lesson (ASITMD) which was developed by Çetin, Bağçeci, Kinay and Şimşek in 2013 and whose validity and reliability studies were made, was used (Çetin et al., 2013). These two scales are a 5-digit Likert-type scale of "absolutely disagree (1), disagree (2), undecided (3), agree (4) and strongly agree (5). In our study, the Cronbach alpha internal consistency reliability coefficients were calculated as .86 for the Marmara Creative Thinking Tendency Scale (MCTTS) and .90 for the Attitude Scale towards Instructional Technologies and Material Design Lesson (ASITMD). There are 6 sub-dimensions which are the search for innovation and the courage, self-discipline, curiosity, doubt, and flexibility in Marmara creative thinking tendency scale. The sub-dimension of the search for innovation requires finding different solutions by giving useful and specific answers about problems or situations; the courage sub-dimension requires to think independently under oppression; the self-discipline sub-dimension requires protecting motivation against the difficulties; the curiosity sub-dimension requires interesting and liking the attractive situations; the doubt sub-dimension requires asking the question of " I wonder if" against a situation, and the flexibility sub-dimension requires acceptance of the mistakes that were made. Attitudes towards Instructional Technologies and Material Design lesson are examined under 3 different sub-dimensions. The first dimension is called "usefulness", the second dimension is "enjoyment" and the third dimension is "repudiation".

\subsection{Analysis of Data}

The data analysis was done on a computer by using SPSS 20.0 computer package program. First of all, the arithmetic mean and standard deviation of the scores of the mathematics teacher candidates' attitude towards the Instructional Technologies and Material Design lesson and their creative thinking tendency, were calculated. The Mann-Whitney U test was used to determine whether there was a significant difference between the views of the teacher candidates in accordance with different variables which was not distributed normally, and the Kruskal Wallis test was used in accordance with the variables showing significant differences. The Pearson moment multiply correlation (simple linear correlation) was calculated to determine the correlation between the creative thinking tendency scores of the mathematics teacher candidates and their scores of attitudes towards Instructional Technologies and Material Design lesson. Linear Regression analysis was used to predict whether there was a significant effect on the creative thinking tendency scores of students and their attitudes towards Instructional Technologies and Material Design lesson.

\section{Findings}

\subsection{First Sub-problem}

The first sub-problem of the study is the "What is the attitude level of mathematics teacher candidates towards Instructional Technologies and Material Design lesson"? The arithmetic mean and standard deviation values of the attitudes of Mathematics teacher candidates towards the Instructional Technologies and Material Design lesson were given in Table 1.

Table 1. Statistical Data of the Attitudes of the Mathematics Teacher Candidates Towards Instructional Technologies and Material Design Lesson

\begin{tabular}{lccr}
\hline Sub-dimensions & N & Mean & Std. deviation \\
\hline Denial & 315 & 2.70 & .595 \\
Enjoyment & 315 & 3.42 & .670 \\
Usefulness & 315 & 3.97 & .714 \\
Attitude & 315 & 3.36 & .430 \\
\hline
\end{tabular}


When Table 1 is examined, it is seen that the view scores of students concentrate on group consisting of "moderate" range in the total score part (2.60-3.39) of grading scale used in data analysis. Mathematics teacher candidates had the lowest score in " Denial " sub-dimension with the 2.70 arithmetic mean and had the highest score in "usefulness" sub-dimension with the 3.97 arithmetic mean. The level of attitudes of mathematics teacher candidates towards Instructional Technologies and Material Design lesson is in "moderate level" with 2.70 (2.60-3.39) in the "Denial " sub-dimension and is in "good level" with 3.42 and 3.97 (3.40-4.19) in "enjoyment" and "usefulness" sub-dimensions. By looking at these data, we can say that attitudes of Mathematics teacher candidates towards the lesson are in moderate level. The fact that it is not gotten score from the "absolutely disagree" option can be considered as an indication that the level of attitude to be determined by the scale does not completely disappear. That the scores of mathematics teacher candidates are in "moderate level" shows that their attitudes towards the lesson sort in ascending way.

\subsection{Second Sub-problem}

The second sub-problem of the study is the question of "Do the attitudes of mathematics teacher candidates towards Instructional Technologies and Material Design lesson differ significantly in accordance with gender"? The hypotheses $\mathrm{H} 0$ and $\mathrm{H} 1$ for this sub-problem can be formulated as follows.

$H O=$ There is no significant difference in the attitudes of the male and female Mathematics teacher candidates towards the Instructional Technologies and Material Design lesson in accordance with gender.

$H 1=$ There is a significant difference in the attitudes of the male and female Mathematics teacher candidates towards the Instructional Technologies and Material Design lesson in accordance with gender.

It was concluded that the data were not normally distributed according to the normality analysis of the data. The data obtained after the $\mathrm{U}$ test which was done for testing the hypothesis and the data showing non-normal distribution are given in Table 2. It is seen that the attitude mean score of the female Mathematics teacher candidates towards the Instructional Technologies and Material Design lesson are higher than the mean score of the male Mathematics teacher candidates in the other sub-dimensions and the attitude scores except from "enjoyment" sub-dimension.

Table 2. U Test Results Showing the Attitudes' Scores of the Mathematics Teacher Candidates Towards Instructional Technologies and Material Design Lesson in Accordance with Gender

\begin{tabular}{lllllcc}
\hline Sub-dimensions & & $\mathrm{N}$ & Mean Rank & Tank Total & Mann-Whitney U & $\mathrm{p}$ \\
\hline Denial & Female & 216 & 163.45 & 35304.50 & 9515.500 & .115 \\
& Male & 99 & 146.12 & 14465.50 & & \\
Enjoyment & Female & 216 & 154.03 & 33270.00 & 9834.000 & .252 \\
& Male & 99 & 166.67 & 16500.00 & & \\
Usefulness & Female & 216 & 158.34 & 34200.50 & \multirow{2}{*}{10619.500} & .923 \\
& Male & 99 & 157.27 & 15569.50 & & \\
Attitude & Female & 216 & 159.04 & 34353.50 & \multirow{2}{*}{10466.500} & .764 \\
& Male & 99 & 155.72 & 15416.50 & & \\
\hline
\end{tabular}

However, in order to determine whether this difference is statistically significant or random, the degree of freedom (SD) obtained as a result of Mann-Whitney $U$ test, the $U$ test value and the level of significance (P) scores were examined.

In order to determine the differences between the attitudes of the male and female mathematics teacher candidates towards the Instructional Technologies and Material Design lesson, the $U$ test significance $p$ values were examined and the significance coefficient of attitude score towards Instructional Technologies and Material Design lesson was found as the $p=0.764>0.05$. Since the significance value was greater than the 0.05 significance criterion, the difference between the attitudes of the mathematics teacher candidates towards the Teaching Technologies and Material Design lesson was found to be statistically insignificant. Despite the difference was found to be insignificant, the attitude levels of females towards Instructional Technologies and Material Design lesson are higher than males in whole sub-dimensions and level of total attitude. We can not generalize the result for all males and female Mathematics teacher candidates according to this insignificant difference, but we can refer the difference for the study group explained above. 


\subsection{Third Sub-problem}

The third sub-problem of the study is the question of "Do the attitudes of mathematics teacher candidates towards Instructional Technologies and Material Design lesson differ significantly in accordance with high school from which they graduated?" The hypotheses $\mathrm{H} 0$ and $\mathrm{H} 1$ for this sub-problem can be formulated as follows.

$H O=$ There is no significant difference between attitudes of Mathematics teacher candidates towards Instructional Technologies and Material Design lesson differ significantly in accordance with high school from which they graduated.

$H 1=$ There is a significant difference between attitudes of Mathematics teacher candidates towards Instructional Technologies and Material Design lesson differ significantly in accordance with high school from which they graduated.

In order to test our hypothesis, the creative thinking scores which were obtained from the Kruskal Wallis $\mathrm{H}$ test made with the non-normal distribution data, are given in Table 3.

Table 3. The Results of Kruskal Wallis Test Which Show the Relationship between the High School from Which They Graduated and Their Attitudes Towards Instructional Technologies and Material Design Lesson

\begin{tabular}{|c|c|c|c|c|c|c|c|}
\hline Factor & $\begin{array}{l}\text { Graduation from hig } \\
\text { school }\end{array}$ & $\mathrm{n}$ & Mean Rank & $\mathrm{sd}$ & Chi-kare & $P$ & $\begin{array}{l}\text { Significant } \\
\text { Diiference }\end{array}$ \\
\hline \multirow[t]{3}{*}{ Denial } & \multirow{3}{*}{$\begin{array}{l}\text { Anatolian High School } \\
\text { Vocational high School } \\
\text { High school }\end{array}$} & 93 & 161.59 & \multirow[t]{3}{*}{2} & \multirow[t]{3}{*}{.289} & \multirow[t]{3}{*}{.865} & \multirow[t]{3}{*}{-} \\
\hline & & 74 & 154.03 & & & & \\
\hline & & 148 & 157.73 & & & & \\
\hline \multirow[t]{3}{*}{ Enjoyment } & \multirow{2}{*}{$\begin{array}{l}\text { Anatolian High School } \\
\text { Vocational high School }\end{array}$} & 93 & 153.29 & \multirow[t]{3}{*}{2} & \multirow[t]{3}{*}{1.957} & \multirow[t]{3}{*}{.376} & \multirow[t]{3}{*}{-} \\
\hline & & 74 & 170.89 & & & & \\
\hline & High school & 148 & 154.51 & & & & \\
\hline \multirow[t]{3}{*}{ Usefulness } & \multirow{3}{*}{$\begin{array}{l}\text { Anatolian High School } \\
\text { Vocational high School } \\
\text { High school }\end{array}$} & 93 & 149.18 & \multirow[t]{3}{*}{2} & \multirow[t]{3}{*}{2.921} & \multirow[t]{3}{*}{.232} & \multirow[t]{3}{*}{-} \\
\hline & & 74 & 172.89 & & & & \\
\hline & & 148 & 156.10 & & & & \\
\hline \multirow[t]{3}{*}{ Attitude } & \multirow{3}{*}{$\begin{array}{l}\text { Anatolian High School } \\
\text { Vocational high School } \\
\text { High school }\end{array}$} & 93 & 150.42 & \multirow[t]{3}{*}{2} & \multirow[t]{3}{*}{2.415} & \multirow[t]{3}{*}{.299} & \multirow[t]{3}{*}{-} \\
\hline & & 74 & 171.76 & & & & \\
\hline & & 148 & 155.88 & & & & \\
\hline
\end{tabular}

According to the variable of graduation from high school, there are differences between the attitude score mean ranking of the mathematics teacher candidates towards Instructional Technologies and Material Design lesson. The ranking in the other sub-dimensions except the denial sub-dimension and in the attitude score is in the form of vocational high schools, high schools and Anatolian high schools. In the case of denial sub-dimension, this ranking formed as Anatolian high school, high school and vocational high school. The fact that the students of the vocational high school study with concrete materials which are the nature of their schools may have influenced this positive attitude. In order to determine the difference between the attitudes of mathematics teacher candidates towards Instructional Technologies and Material Design lesson and the high school from which they graduated, U test, significance $\mathrm{p}$ values were examined, and the significance coefficient of attitude score towards Instructional Technologies and Material Design lesson was found as the $p=0.299>0.05$. Since the significance value was greater than the 0.05 significance criterion, the difference between the attitudes of mathematics teacher candidates towards the Instructional Technologies and Material Design lesson was found to be statistically insignificant in the context of graduation from high school. The attitudes of the mathematics teacher candidates, graduated from the vocational high school, towards the Instructional Technologies and Material Design lesson are higher than those who were graduated from high school and Anatolian high school in the other sub-dimensions except "denial" sub-dimension and in the level of total attitude. For the mathematics teacher candidates participating in this research, we can say that the attitudes of the mathematics teacher candidates, graduated from all vocational high schools, towards Instructional Technologies and Material Design lesson are in high level in accordance with this result. From this point of view, it can be said that 
ITMD lesson and its applications do not affect the Mathematics teacher candidates who have graduated from vocational high school negatively and that it does not make them be nervous and they do not waste their time. But we can not generalize this result for all mathematics teacher candidates who were graduated from vocational high school.

\subsection{Fourth Sub Problem}

The fourth sub-problem of the study is the question of "What is the creative thinking tendency level of Mathematics teacher candidates?" The arithmetic mean and standard deviation values regarding creative thinking tendencies of Mathematics teacher candidates are given in Table 4.

Table 4. Statistical Data of Mathematics Teacher Candidates Regarding Their Creative Thinking Tendencies

\begin{tabular}{lrrc}
\hline \multicolumn{1}{c}{ Sub-dimensions } & $\mathrm{N}$ & \multicolumn{1}{c}{ Mean } & Std. Deviatio \\
\hline Self-discipline & 315 & 2.33 & .57708 \\
Search for Innovation & 315 & 2.38 & .52565 \\
Courage & 315 & 3.64 & .69763 \\
Curiosity & 315 & 4.10 & .60624 \\
Doubt & 315 & 3.99 & .65751 \\
Flexibility & 315 & 4.08 & .57708 \\
Creativity & 315 & 3.88 & .44339 \\
\hline
\end{tabular}

When Table 4 is examined, it is seen that the view scores of students concentrate on group consisting of "good" range in the total score part (3.40 - 4.19) of grading scale used in data analysis.

The students had the lowest score in "self-discipline" sub-dimension with the 2.33 arithmetic mean, and had the highest score in "curiosity" sub-dimension with the 4.10 arithmetic mean. It is seen that the creativity of the students is in "low level" in the "self-discipline" sub-dimension with 2.33 (1.80-2.59) and is in "good level" in the "flexibility" sub-dimension with 4.08 (3.40-4.19). By looking at these data, we can say that self disciplines of the students are low and their curiosity is high. The fact that it is not gotten score from the "absolutely disagree" option can be considered as an indication that the level of creativity to be determined by the scale does not completely disappear. That the teacher candidates score in "low level and above" shows that their creativities sort in ascending way.

\subsection{Fifth Sub Problem}

The fifth sub-problem of the study is the question of "Is there any correlation between the creative thinking tendency scores of the Mathematics teacher candidates and their scores of attitudes towards Instructional Technologies and Material Design lesson?" In order to answer this sub-problem question, correlation statistical data were examined, and the correlation values belonging to the creative thinking of Mathematics teacher candidates and their attitudes towards Instructional Technologies and Material Design lesson were given in table 5.

Table 5. The Correlation Matrix Belonging to the Creative Thinking and the Attitude Towards Instructional Technologies and Material Design Lesson

\begin{tabular}{|c|c|c|}
\hline & & $\begin{array}{l}\text { The Attitude towards Instructional } \\
\text { Technologies and Material Design Lesson }\end{array}$ \\
\hline Creative Thinking & $\mathrm{r}$ & .027 \\
\hline
\end{tabular}

When Table 5 is examined, the simple linear correlation operation done for finding out whether there is a relationship between the creative thinking of Mathematics teacher candidates and their attitudes towards Instructional Technologies and Material Design lesson, shows that there is a positive insignificant relationship between the creative thinking of teacher candidates and their attitudes towards Instructional Technologies and Material Design lesson $(\mathrm{r}=$ $0.02, \mathrm{p}=.632<0.00)$ 
Table 6. The Attitude Correlation Matrix of Usefulness Sub-Dimension of Creative Thinking and Instructional Technologies and Material Design Lesson

\begin{tabular}{lll}
\hline & $\begin{array}{l}\text { Usefulness sub-dimension attitude } \\
\text { towards Instructional Technologies and } \\
\text { Material Design lesson }\end{array}$ \\
\hline Creative Thinking & $\mathrm{r}$ & $.785^{*}$ \\
\hline Correlation is not significant at the 0.01 level (2-tailed). &
\end{tabular}

According to Table 6, the simple linear correlation operation done for finding out whether there is a relationship between creative thinking of teacher candidates and their creativity sub-dimension attitudes towards Instructional Technologies and Material Design lesson, shows that there is a positive significant relationship between the creative thinking of mathematics teacher candidates and their creativity sub-dimension attitudes towards Instructional Technologies and Material Design lesson $(r=0.01, p=.632<0.00)$.

\section{Conclusion and Discussion}

When we examine the attitudes of mathematics teacher candidates towards Instructional Technologies and Material Design lesson, we can say that the attitudes of mathematics teacher candidates are in moderate level. Ekici (2008), Kinay and others (2015) found that attitudes of mathematics teacher candidates towards ITMD lesson were in high level. However, it is seen in our study that the attitudes of mathematics teacher candidates towards the Instructional Technologies and Material Design lesson are at the "lowest" level in the "denial" sub-dimension and are at "good" level in the "usefulness" sub-dimension. Nobody marked "absolutely disagree" option. This result shows that there are very few numbers of candidates who have negative thinking about ITMD lesson and subjects about this lesson. However, it can be said that this lesson for Mathematics teacher candidates contributes to the development of materials related to their own fields and to use of these materials, and to make them understand the importance of the notion of using material. In addition, it can be said that the creativity of the Mathematics teacher candidates improved and their motivations increased because of the applications. It was determined that the Mathematics teacher candidates who took the ITMD lesson felt ready to prepare material. Additionally, it was found that the ITMD lesson introduces the teaching principals, contributes to the development of the skills such as creativity, effective presentation, classroom management, etc. (Güneş \& Karakuş, 2009; Sönmez et al., 2006). This study supports our study.

When the attitudes of the mathematics teacher candidates towards the Instructional Technologies and Material Design lesson were examined in accordance with gender, the mean score of the attitude of the female mathematics teacher candidates towards the Instructional Technologies and Material Design lesson was slightly higher than mean score of male mathematics teacher candidates in attitude score and in the all sub-dimensions except "enjoyment" sub-dimension. We can say that the difference between the levels according to genders is statistically insignificant. Despite the difference was found to be insignificant, the attitude levels of females towards Instructional Technologies and Material Design lesson are higher than males in whole sub-dimensions and level of total attitude. When the views of Alım (2015) in terms of ITMD lesson learning outcomes of teacher candidates were examined, there was no significant difference according to gender. This also supports our study.

The fact that the students of the vocational high school study with concrete materials which are the nature of their schools may have influenced this positive attitude. It can be said that a lesson containing this type of application has a negative effect on the Mathematics teacher candidates who graduated from the Anatolian High School. The reason for this may be that the theoretical lessons are predominantly in Anatolian High Schools and these schools concentrates on preparation for the entrance examination to the University intensively. The significance coefficient belonging to the variable of graduation from high school and attitude score towards Instructional Technologies and Material Design lesson was found to be as the $\mathrm{p}=0.299>0.05$. This difference was not found to be statistically significant. We can say that the attitudes of the mathematics teacher candidates, graduated from all vocational high schools, towards Instructional Technologies and Material Design lesson are in high level in accordance with this result. But we can not generalize this result for all mathematics teacher candidates who were graduated from vocational high school. 
The Marmara Creative Thinking Tendency Scale was applied to determine the level of creative thinking tendencies of the mathematics teacher candidates, and it is seen that they concentrate on the group consisting of "good" range in the total score part. Mathematics teacher candidates had the lowest score in the "self-discipline" sub-dimension and had the highest score in the "curiosity" sub-dimension.

Finally, when it is examined whether there is any correlation between the creative thinking tendency scores of mathematics teacher candidates in this research and their attitude scores towards Instructional Technologies and Material Design lesson, it is seen that there is a positive and insignificant relationship between them. However, it is seen that there is a positive and significant relationship between the creative thinking tendency scores of mathematics teacher candidates in this research and their creativity 'usefulness' sub-dimension attitude scores towards Instructional Technologies and Material Design lesson.

\section{Recommendations}

- Mathematics teacher candidates can develop their creative thinking tendencies, they can speak freely and are not being judged, and that provides creative thinking to emerge, should be formed.

- It should be ensured them to improve themselves and raise their awareness about Mathematics education.

- After each topic is explained, the environments in which they prepare material in the project studies related with subjects should be created, and their creativities should be developed.

\section{References}

Akkoyunlu, B. (2002). Educational technology in Turkey: Past, present and future. Educational Media International, 39(2), 165-173. https://doi.org/10.1080/09523980210155352

Alım, M. (2007). Öğretim Teknolojileri ve Materyal Geliştirme (ÖTMG) Dersinin Önemi ve Öğretim Sürecine Yönelik Öneriler. Doğu Coğrafya Dergisi, 12, 17.

Alım, M. (2012). Coğrafya Dersleri İçin Materyal Tasarımı. Doğu Coğrafya Dergisi, 17, 27.

Alım, M. (2015). Coğrafya öğretmeni adaylarının öğretim teknolojileri ve material tasarımı geliştirme dersinde elde ettikleri kazanımlar, Acquisitions of Prospective Geography Teachers in The Instructional Technology and Material Design/Development Course, 1-10.

Aslan, N., \& Cansever, B. A. (2009). Eğitimde Yaratıcılığın Kullanımına İlişkin Öğretmen Tutumları. TUBAV Bilim Dergisi, 2(3), 333-340.

Bakaç, E., \& Özen R. (2017) Öğretmen adaylarının materyal tasarımı öz-yeterlik inanç düzeylerinin Teknolojik Pedagojik Alan Yeterlikleri Bağlamında İncelenmesi. Ahi Evran Üniversitesi Kırşehir Eğitim Fakültesi Dergisi (KEFAD), 18(2), 613-632.

Bakaç, E., \& Özen, R. (2016). Öğretmen adaylarının öğretim teknolojileri ve materyal tasarımı dersine yönelik tutumları, yaratıcılık algıları ve öz-yeterlik inançları arasındaki ilişki. Abant İzzet Baysal Üniversitesi Eğitim Fakültesi Dergisi, 16(1), 41-61.

Beyhan Ö. (2013) The correlation of students' views on constructivist teaching environment and teachers' student control ideologies. Educational Research and Reviews, 8(9), 553-559.

Birişçi, S., \& Karal, H. (2011). Öğretmen adaylarının bilgisayar destekli ortamda materyal tasarlarken işbirlikli çalışmalarının yaratıcı düşünme becerilerine etkisi. Ahi Evran Üniversitesi Eğitim Fakültesi Dergisi, 12(2), 203-219.

Çetin, B., Bağçeci, B., Kinay, İ., \& Şimşek, Ö. (2013). Öğretim Teknolojileri Ve Materyal Tasarımı Dersine Yönelik Tutum Ölçeğinin (Ötmtdytö) Geliştirilmesi: Geçerlilik Ve Güvenirlik Çalışması. International Journal of Social Sciences, 6(2), 697-713.

Demirel, Ö. (2010). Eğitim Sözlüğü (4. baskı). Ankara: Pegem Akademi.

Edwards, A. L. (2006). Creatures of habit and creatures of change: Essays on art, literature and society. Santa Rosa, 


\section{CA: Black Sparrow Press.}

Ekici, G. (2008). Öğretmen Adaylarının Öğretmenlik Meslek Bilgisi Derslerine Yönelik Tutumları ile Öğrenme Biçimlerinin Değerlendirilmesi. Yüzüncü Yll Üniversitesi Eğitim Fakültesi Dergisi, V(I), 111-132.

Erden, M. (1995). Öğretmen Adaylarının Öğretmenlik Sertifikası Derslerine Yönelik Tutumları. Hacettepe Üniversitesi Ĕ̆itim Fakültesi Dergisi, 11, 99-104.

Erlendsson, Jon. (1999). The Role of Creativity, University of Iceland. Retrieved from http://www.hi.is/ joner/eaps/cq_cr04.htm

Fraenkel, J. R., \& Wallen, N. E. (2000). How to design and evaluate research in education. New York: McGraw-Hill.

Gündüz, Ş., \& Odabaşı. F. (2004). Bilgi Çağında Öğretmen Adaylarının Eğitiminde Öğretim Teknolojileri ve Materyal Geliştirme Dersinin Önemi. The Turkish Online Journal of Educational Technology, 3(1), 43-48.

Güneş G., \& İskenderoğlu T. A. (2014), İlköğretim Matematik Öğretmeni Adaylarının Öğretim Teknolojileri ve Materyal Tasarımı Dersine Yönelik Yaklaşımları. Gazi Üniversitesi Eğitim Fakültesi Dergisi, 34(3), 469-488.

Gür H., \& Kandemir, M. A. (2006). Creativity and Mathematics Education. İlköğretim Online, 5(1), 65-72.

İnan, C. (2006). "Matematik Öğretiminde Materyal Geliştirme ve Kullanma” International Educational Technologies Congress, Doğu Akdeniz University, May 2006, Cyprus. Journal of Ziya Gökalp Education Faculty, 1(7), 47-56.

İnceoğlu, M. (2010). Tutum Algl İletişim (5. Baskı). İstanbul: Beykent University Publications.

İşleyen T., \& Küçük B. (2013). Öğretmen adaylarının yaratıcı düşünme düzeylerinin farklı değişkenler açısından incelenmesi. Mustafa Kemal University Journal of Social Sciences Institute, 10(21), 199-208.

Kaya, Z. (2006). Öğretim teknolojileri ve materyal geliştirme. Ankara: Pegem Akademi Publications.

Kazanc1, O. (1989). Eğitimde ne düşünmek mi nasıl düşünmek mi?. Çağdaş Eğitim Dergisi, 14(145),19-24.

Kinay, İ., Şimşek, Ö., Bağçeci, B., \& Çetin B. (2015). Öğretmen Adaylarının Öğretim Teknolojileri ve Materyal Tasarımı (Ötmt) Dersine Yönelik Tutumlarının Çeşitli Değişkenler Açısından İncelenmesi, Dicle Üni. Ziya Gökalp Eğitim Fakültesi Dergisi, 25, 119-135. https://doi.org/10.14582/DUZGEF.511

Kolburan Geçer, A. (2010). Teknik ögretmen adaylarının öğretim teknolojisi ve materyal geliştirme dersine yönelik deneyimleri. Yüzüncü Yıl Üniversitesi, Eğitim Fakültesi Dergisi. Cilt: VII, Sayı: II, 1-25.

McMillan, J. H., \& Schumacher, S. (2006). Research in education: Evidence-based inquiry (6th ed.). Boston, MA: Allyn and Bacon.

Özer, Ö., \& Tunca, N. (2014). Öğretmen Adaylarının Materyal Hazırlama Ve Kullanmaya Yönelik Görüşleri. Route Educational and Social Science Journal, 1(3), 214-229.

Özgenel, M. \& Çetin, M. (2017). Marmara yaratıcı düşünme eğilimleri ölçeğinin geliştirilmesi: Geçerlik ve güvenirlik çalışması. Marmara Üniversitesi Atatürk Ĕ̈itim Fakültesi Eğitim Bilimleri Dergisi, 46, 113-132.

Şahin, T. Y., \& Yıldırım, S. (2004). Öğretim Teknolojileri ve Materyal Geliştirme. Ankara: Anı Yayıncılık.

Saka A. Z., \& Saka A. (2005). Öğretmen Adaylarının Öğretim Teknolojileri ve Materyal Geliştirme Dersinde Mesleki Beceri Geliştirme Düzeyi, Sakarya Örneği. Sakarya üniversitesi Eğitim Fakültesi Dergisi, 10, 81-89.

Sönmez, Ö. F., Çavuş, H., \& Merey, Z. (2009). Coğrafya öğretmenlerinin öğretim teknolojileri ve materyalleri kullanma düzeyleri. Sosyal Bilimler Araştırmaları Dergisi, 2, 213-228.

TDK (2015). http://www.tdk.gov.tr/

Türk Dil Kurumu (1995). Türkçe Sözlük. Ankara: Türk Tarih Kurumu Yayınları.

Tutkun, Ö. F., \& Koç, M. (2001). Öğretim Teknolojileri ve Materyal Geliştirme Dersinin Hedeflerine Ulaşma Derecesi. Uluslararası Eğitim Teknolojileri Sempozyumu ve Fuarı, 28-30 Kasım, Sakarya Üniversitesi, Sakarya.

Uzungöz, A., Aktepe, V., \& Gündüz, M. (2017). Öğretim teknolojileri ve materyal tasarımı dersinin, mesleki açıdan 
kazandırdıklarına ilişkin öğretmen adaylarının görüşleri: Nitel bir çalışma. Eğitimde Nitel Araştırmalar Dergisi Journal of Qualitative Research in Education, 5(3), 317-339. 